\title{
Low Concentrations of Arsenite Target the Intraluminal Inositol 1, 4, 5-Trisphosphate Receptor/Ryanodine Receptor Crosstalk to Significantly Elevate Intracellular $\mathrm{Ca}^{2+}$
}

\author{
Andrea Guidarelli, Mara Fiorani, and Orazio Cantoni \\ Department of Biomolecular Sciences, University of Urbino Carlo Bo, Urbino, Italy
}

Received May 7, 2018; accepted July 27, 2018

\begin{abstract}
Arsenite is an established human carcinogen that induces cytotoxic and genotoxic effects through poorly defined mechanisms involving the formation of reactive oxygen species (ROS) and deregulated $\mathrm{Ca}^{2+}$ homeostasis. We used variants of the U937 cell line to address the central issue of the mechanism whereby arsenite affects $\mathrm{Ca}^{2+}$ homeostasis. We found that 6-hour exposure to the metalloid $(2.5 \mu \mathrm{M})$, although not associated with an immediate or delayed toxicity, causes a significant increase in the intracellular $\mathrm{Ca}^{2+}$ concentration $\left(\left[\mathrm{Ca}^{2+}\right]_{i}\right)$ through a mechanism characterized by the following components: 1) it was not affected by ROS produced under the same conditions; 2) a small amount of $\mathrm{Ca}^{2+}$ was mobilized from the inositol-1,4,5-trisphosphate receptor $\left(\mathrm{IP}_{3} \mathrm{R}\right)$, and this response was not augmented by greater concentrations of the metalloid; 3 ) large amounts of $\mathrm{Ca}^{2+}$ were instead dose
\end{abstract}

dependently mobilized from the ryanodine receptor (RyR) in response to $\mathrm{IP}_{3} \mathrm{R}$ stimulation; 4) the cells maintained an intact responsiveness to agonist-stimulated $\mathrm{Ca}^{2+}$ mobilization from both channels; 5) arsenite, even at 5-10 $\mu \mathrm{M}$, failed to directly mobilize $\mathrm{Ca}^{2+}$ from the RyR; and 6) arsenite failed to enhance $\mathrm{Ca}^{2+}$ release from the RyR under conditions in which the $\left[\mathrm{Ca}^{2+}\right]_{\mathrm{i}}$ was increased by either RyR agonists or ionophore-stimulated $\mathrm{Ca}^{2+}$ uptake. We therefore conclude that arsenite elevates the $\left[\mathrm{Ca}^{2+}\right]_{\mathrm{i}}$ by directly targeting the $\mathrm{IP}_{3} \mathrm{R}$ and its intraluminal crosstalk with the RyR. This mechanism likely mediates mitochondrial superoxide formation, downstream damage on various biomolecules (including genomic DNA), and mitochondrial dysfunction/ apoptosis eventually occurring after longer incubation to, or exposure to greater concentrations of, arsenite.

\section{Introduction}

Intracellular mobilization of $\mathrm{Ca}^{2+}$, an event that regulates an array of different physiologic functions, as well as pathologically and toxicologically relevant dysfunctions, is mediated predominantly by two separate, but nevertheless related, $\mathrm{Ca}^{2+}$ channels, the inositol 1,4,5-trisphosphate receptor $\left(\mathrm{IP}_{3} \mathrm{R}\right)$ and the ryanodine receptor (RyR) (Berridge, 2016; Chernorudskiy and Zito, 2017; Meissner, 2017). These $\mathrm{Ca}^{2+}$ channels are located on the surface of the endoplasmic reticulum (ER) and share numerous similarities, including a complex regulation mediated by reactive oxygen species (ROS) (Gorlach et al., 2015; Chernorudskiy and Zito, 2017; Csordás et al., 2018). The significance of the $\mathrm{IP}_{3} \mathrm{R}$ - and RyR-regulated mechanisms can be easily appreciated in physiologic as well as pathologic conditions (Clapham, 2007; Berridge, 2016; Raffaello et al., 2016; Chernorudskiy and Zito, 2017; Csordás et al., 2018). Toxic treatments often deregulate $\mathrm{Ca}^{2+}$ homeostasis, with important consequences on the activity of

This work was supported by Ministero dell'Università e della Ricerca Scientifica e Tecnologica, Programmi di Ricerca Scientifica di Rilevante Interesse Nazionale, 2015, [Grant 2015MJBEM2-003 to O.C.].

https://doi.org/10.1124/jpet.118.250480. enzymatic systems/signal transduction pathways eventually associated with the formation of large amounts of ROS.

Trivalent arsenic, a widely distributed environmental toxic metalloid and human carcinogen (Flora, 2011; Minatel et al., 2018), produces deleterious effects in an array of molecular targets, presumably through its direct binding to protein thiols and indirectly through the intermediate formation of ROS (Flora, 2011). These effects include DNA strand scission, inhibition of DNA repair, altered gene expression, mitochondrial dysfunction and permeability transition, ER stress, autophagy, and apoptosis (Flora, 2011). Not surprisingly, various studies have investigated the effects of trivalent arsenic on $\mathrm{Ca}^{2+}$ homeostasis.

This is especially true for $\mathrm{As}_{2} \mathrm{O}_{3}$ (Hoonjan et al., 2018), a compound widely used as an antileukemic drug. Although the number of studies addressing the effects of sodium arsenite is significantly lower, their outcomes nevertheless provide information for an increased intracellular concentration of $\mathrm{Ca}^{2+}$ $\left(\left[\mathrm{Ca}^{2+}\right]_{\mathrm{i}}\right)$; however, the increased is mediated by often undefined mechanisms (Chen et al., 2002; Banerjee et al., 2011; Suriyo et al., 2012; Pachauri et al., 2013). Some studies have linked the release of cation to activation of phospholipase C (PLC) and further downstream signaling via inositol 1,4,5-trisphosphate

ABBREVIATIONS: 2-APB, 2-aminoethoxydiphenyl borate; ANOVA, analysis of variance; $\left[\mathrm{Ca}^{2+}\right]_{\text {i }}$, intracellular concentration of $\mathrm{Ca}^{2+}$; $\mathrm{Cf}$, caffeine; $\mathrm{CICR}, \mathrm{Ca}^{2+}$-induced $\mathrm{Ca}^{2+}$ release; $\mathrm{CmC}$, 4-chloro-m-cresol; $\mathrm{D}$ cells, differentiated cells; ER, endoplasmic reticulum; $\mathrm{P}_{3} \mathrm{R}$, inositol 1,4,5trisphosphate receptor; mitoO ${ }_{2}^{-}$, mitochondrial superoxide; PLC, phospholipase C; RD cells, respiration-deficient cells; ROS, reactive oxygen species; RP cells, respiration-proficient cells; Ry, ryanodine; RyR, ryanodine receptor; U-73122, 1-(6-((17 $\beta$-3-methoxyestra-1,3,5(10)-trien-17yl)amino)hexyl)-1H-pyrrole-2,5-dione. 
through $\mathrm{IP}_{3} \mathrm{Rs}$ (Chen et al., 2002; Suriyo et al., 2012), but unfortunately these studies did not address involvement of the RyR. Finally, other studies have reported effects of arsenite associated with either a decreased $\mathrm{Ca}^{2+}$ response of primary cheratinocytes to $\mathrm{IP}_{3} \mathrm{R}$ agonists (Hsu et al., 2012) or, rather, enhanced $\mathrm{Ca}^{2+}$ responses mediated by phenylephrine in vascular smooth muscle cells (Lee et al., 2005).

It therefore appears that arsenite targets the $\mathrm{IP}_{3} \mathrm{R}$, but critical details of the overall scenario are still missing. For example, it is unclear whether the RyR, which presents critical cysteins and releases $\mathrm{Ca}^{2+}$ in response to ROS or specific thiol-reactive agents (Chernorudskiy and Zito, 2017; Meissner, 2017), is involved in the $\mathrm{Ca}^{2+}$ response elicited by the metalloid. In addition, the RyR could be involved through the so-called $\mathrm{Ca}^{2+}$-induced $\mathrm{Ca}^{2+}$ release (CICR) event; however, the major problems for correct interpretation of the available information concern use of different cell types and exposure conditions in the different studies. Most of these studies used high and toxic concentrations of arsenite, possibly triggering multiple mechanisms affecting $\mathrm{Ca}^{2+}$ homeostasis and ROS release.

Information is therefore needed to learn more about the mechanism(s) whereby low concentrations of the metalloid affect $\mathrm{Ca}^{2+}$ homeostasis. These conditions allow the detection of effects specifically induced by the metalloid in the absence of confounding events resulting from energy depletion and/or toxicity. Understanding the molecular bases of these events is particularly important since deregulated $\mathrm{Ca}^{2+}$ homeostasis is a potential trigger for ROS formation and hence for the ensuing formation of potentially mutagenic DNA lesions. As a final note, these same mechanisms are also of potential relevance for the triggering of events promoting mitochondrial permeability transition-dependent apoptosis observed after prolonged exposure to the same arsenite concentrations or after exposure to greater concentrations of the metalloid (Guidarelli et al., 2016a, 2017; Fiorani et al., 2018).

The present study was therefore designed to fill some of the gaps left by previous studies. In particular, using the well characterized and versatile U937 cell line, also used in our previous studies (Guidarelli et al., 2016a, 2017), we found that arsenite elevates the $\left[\mathrm{Ca}^{2+}\right]_{i}$ through the sequential mobilization of small and large amounts of the cation from the $\mathrm{IP}_{3} \mathrm{R}$ and RyR, respectively. Under these conditions, cells maintained an intact responsiveness to agonist-stimulated $\mathrm{Ca}^{2+}$ mobilization from both channels, and the large $\mathrm{Ca}^{2+}$ response mediated by the metalloid appeared entirely dependent on direct effects on the intraluminal crosstalk between the two $\mathrm{Ca}^{2+}$ channels.

\section{Materials and Methods}

Chemicals. Sodium arsenite, 1-(6-((17 $\beta$-3-methoxyestra-1,3,5(10)-trien17-yl)amino)hexyl)-1H-pyrrole-2,5-dione (U-73122), 2-aminoethoxydiphenyl borate (2-APB), ryanodine (Ry), caffeine (Cf), 4-chloro-m-cresol (4$\mathrm{CmC}$ ), ATP, histamine, A23187, thapsigargin, rotenone, ascorbic acid (AA), $\mathrm{H}_{2} \mathrm{O}_{2}$, as well most of the reagent-grade chemicals, were purchased from Sigma-Aldrich (Milan, Italy). Fluo-4- acetoxymethyl ester was from Molecular Probes (Leiden, The Netherlands).

Cell Culture and Treatment Conditions. U937 human myeloid leukemia cells were cultured in suspension in RPMI 1640 medium (Sigma-Aldrich) supplemented with 10\% fetal bovine serum (Euroclone, Celbio Biotecnologie, Milan, Italy), penicillin (100 U/ml), and streptomycin $(100 \mu \mathrm{g} / \mathrm{ml})$ (Euroclone), at $37^{\circ} \mathrm{C}$ in T-75 tissue culture flasks (Corning Inc., Corning, NY) gassed with an atmosphere of 95\% air-5\% $\mathrm{CO}_{2}$. These cells were differentiated to monocytes by 4 days of growth in culture medium supplemented with $1.3 \%$ dimethylsulfoxide, as previous described (Scotti et al., 2018). U937 cells were made respiration-deficient as indicated in Guidarelli et al. (2016b).

Sodium arsenite was prepared as a $1 \mathrm{mM}$ stock solution in saline A (140 mM NaCl, $5 \mathrm{mM} \mathrm{KCl,} 4 \mathrm{mM} \mathrm{NaHCO}_{3}$, and $5 \mathrm{mM}$ glucose; $\mathrm{pH} 7.4$ ) and stored at $4^{\circ} \mathrm{C}$. Cells $\left(1.5 \times 10^{5}\right.$ cells $\left./ \mathrm{ml}\right)$ were exposed to arsenite in complete RPMI 1640 culture medium. A $10 \mathrm{mM}$ AA stock solution was prepared in extracellular buffer (15 mM Hepes, $135 \mathrm{mM} \mathrm{NaCl}, 5 \mathrm{mM}$ $\mathrm{KCl}, 1.8 \mathrm{mM} \mathrm{CaCl}_{2}, 0.8 \mathrm{mM} \mathrm{MgCl}_{2}, \mathrm{pH} 7.4$ ) immediately before use. Cells $\left(1 \times 10^{6}\right.$ cells $\left./ \mathrm{ml}\right)$ were treated with AA in extracellular buffer supplemented with $0.1 \mathrm{mM}$ dithiothreitol for 15 minutes at $37^{\circ} \mathrm{C}$. Stability of AA under these conditions was assessed by monitoring the absorbance at $267 \mathrm{~nm}$ for 15 minutes $\left(\varepsilon_{267}=14,600 \mathrm{M}^{-1} \mathrm{~cm}^{-1}\right)$.

Measurement of Intracellular Free $\mathbf{C a}^{2+}$ Levels. Cells were treated for 20 minutes with $4 \mu \mathrm{M}$ Fluo-4-acetoxymethyl ester and subsequently exposed for further 10 minutes to selected $\mathrm{IP}_{3} \mathrm{R}$ or RyR agonists. In other experiments, cells were exposed for increasing time intervals to arsenite, and Fluo-4-acetoxymethyl ester was added to the culture medium in the last 30 minutes of incubation. After the treatments, cells were washed three times with saline A and immediately analyzed by fluorescent microscopy. Fluorescence images were captured with a BX-51 microscope (Olympus, Milan, Italy), equipped with a SPOT-RT camera unit (Diagnostic Instruments; Delta Sistemi, Rome, Italy) using an Olympus LCAch 40 x/0.55 objective lens. The excitation and emission wavelengths were 488 and $515 \mathrm{~nm}$, respectively, with a 5 -nm slit width for both emission and excitation. Images were collected with exposure times of 100-400 milliseconds, digitally acquired and processed for fluorescence determination at the single cell level on a personal computer using NIH ImageJ software. Mean fluorescence values were determined by averaging the fluorescence values of at least 50 cells/treatment condition in each experiment.

Cytotoxicity Assay. The number of viable cells was estimated with the trypan blue exclusion assay. Briefly, an aliquot of the cell suspension was diluted $1: 2(\mathrm{v} / \mathrm{v})$ with $0.4 \%$ trypan blue, and the viable cells (i.e., those excluding trypan blue) were counted using the hemocytometer.

Aconitase Activity. Cells were washed twice with saline A, resuspended in lysis buffer $(50 \mathrm{mM}$ Tris-HCl, $2 \mathrm{mM}$ Na-citrate, $0.6 \mathrm{mM} \mathrm{MnCl}_{2}, \mathrm{pH} 7.4$ ), and finally sonicated three times on ice by using the Sonicator ultrasonic liquid processor XL (Heat SystemUltrasonics, Inc., Jamestown, NY) operating at $20 \mathrm{~W}$ (10 seconds). The resulting homogenates were centrifuged for 5 minutes at $18,000 \mathrm{~g}$ at $4^{\circ} \mathrm{C}$. Aconitase activity was determined spectrophotometrically in the supernatants at $340 \mathrm{~nm}$, as described in Gardner (2002).

ATP Determination. Cells were washed twice with saline A and resuspended in ice-cold 5\% perchloric acid. After a 10-minute incubation in an ice bath, the samples were centrifuged for 5 minutes at $10,000 \mathrm{~g}$. The supernatants were neutralized with $3 \mathrm{M} \mathrm{K}_{2} \mathrm{CO}_{3}$, and the precipitates were removed by centrifugation. Then $10 \%(\mathrm{v} / \mathrm{v})$ $1 \mathrm{M} \mathrm{KH}_{2} \mathrm{PO}_{4}$ ( $\mathrm{pH}$ 6.5) was added to the nucleotide-containing supernatants. The samples were then filtered through $0.22-\mu \mathrm{m}$-pore microfilters and analyzed for ATP content by reversed-phase high-performance liquid chromatography (Stocchi et al., 1985) using a $25 \mathrm{~cm} \times 4.6-\mathrm{mm}, 5-\mu \mathrm{m}$ Supelco Discovery C18 column (Supelco, Bellefonte, PA).

Measurement of $\mathbf{C a}^{2+}$-ATPase Activity. Cells were washed twice with saline A, resuspended in saline A, and finally sonicated three times on ice, as detailed already. The resulting homogenates were analyzed for $\mathrm{Ca}^{2+}$-ATPase activity by using a commercial Kit (MyBioSource, San Diego, CA).

Statistical Analysis. The results are expressed as means \pm S.D. Statistical differences were analyzed by one-way analysis of variance (ANOVA) followed by Dunnett's test for multiple comparison or twoway ANOVA followed by Bonferroni's test for multiple comparison. $P<0.05$ was considered significant. 


\section{Results}

Selection of the Experimental Cell Types. We investigated the effects of arsenite on $\mathrm{Ca}^{2+}$ homeostasis and focused our attention on the role of both the $\mathrm{IP}_{3} \mathrm{R}$ and RyR. For this purpose, we decided to use U937 cells, which express both channels (Sugiyama et al., 1994; Clementi et al., 1998; Hosoi et al., 2001; Guidarelli et al., 2009) and uniquely generate mitochondrial superoxide $\left(\mathrm{mitoO}_{2}^{-}\right)$in response to arsenite (Guidarelli et al., 2016a,b, 2017; Fiorani et al., 2018). As we reported elsewhere, mitoO ${ }_{2}^{-}$formation could be selectively prevented with use of complex I inhibitors, by the respirationdeficient phenotype, or by a short-term pre-exposure to a very low AA (Guidarelli et al., 2016a,b, 2017; Fiorani et al., 2018), thereby providing optimal conditions to address the question of whether $\mathrm{Ca}^{2+}$ mobilization from intracellular stores is mediated by ROS. There is, however, a final relevant advantage offered by these cells to conveniently address some of the questions asked in the present study. Indeed, U937 cells can be easily differentiated to monocytes, and these conditions are associated with downregulation of the RyR (Guidarelli et al., 2009), thereby providing a useful approach to address the specificity of the effects mediated by RyR inhibitors.

The present study was therefore performed using promonocytic U937 cells, referred to here as respiration-proficient cells (RP cells), respiration-deficient cells (RD cells), and differentiated cells (D cells). RD and D cells were both derived from RP cells and are characterized by similar ATP levels (present study) and antioxidant defense (Guidarelli et al., 2006, 2009). Whereas D cells presented typical features of monocytes, and were therefore unable to proliferate (Guidarelli et al., 2009), RP and RD cells maintained a similar morphology and displayed identical growth kinetics (Guidarelli et al., 2016b).

Preliminary Characterization of the $\mathrm{Ca}^{2+}$ Response to Selected Agonists. Experiments were initially performed to characterize the $\mathrm{Ca}^{2+}$ response of $\mathrm{RP}, \mathrm{RD}$, and $\mathrm{D}$ cells to $\mathrm{IP}_{3} \mathrm{R}$ and RyR agonists. As indicated in Fig. 1, A-C, a 10-minute exposure to increasing concentrations of ATP caused a comparable, dose-dependent increase in $\left[\mathrm{Ca}^{2+}\right]_{\mathrm{i}}$ in the three cell types, suppressed by 2 -APB, a specific $\mathrm{IP}_{3} \mathrm{R}$ antagonist (Berridge, 2016), or U-73122, a PLC inhibitor (Cardenas et al., 2016), with, however, a different sensitivity to Ry, an RyR inhibitor (Meissner, 2017). Ry marginally reduced the increase in $\left[\mathrm{Ca}^{2+}\right]_{i}$ detected in $\mathrm{RP}$ or RD cells, with no apparent effects measured in D cells. Similar results were obtained by replacing ATP with histamine, another $\mathrm{IP}_{3} \mathrm{R}$ agonist (Hill et al., 1997) (Fig. 1G). Note that the effects mediated by $100 \mu \mathrm{M}$ ATP on $\left[\mathrm{Ca}^{2+}\right]_{\mathrm{i}}$ were not further increased at up to 10 times greater concentrations (data not shown).

Cf, an RyR agonist (Meissner, 2017), also promoted an increase in $\left[\mathrm{Ca}^{2+}\right]_{\mathrm{i}}$ in RP- (Fig. 1D) and RD (Fig. 1E) cells, in both circumstances insensitive to 2-APB, or U-73122, and suppressed by Ry. Cf, however, failed to increase $\left[\mathrm{Ca}^{2+}\right]_{i}$ in $\mathrm{D}$ cells (Fig. 1F). Similar results were obtained using 4-CmC, another RyR agonist (Meissner, 2017), in the place of $\mathrm{Cf}(\mathrm{Fig} .1 \mathrm{H})$. The $\mathrm{Ca}^{2+}$ response mediated by $\mathrm{Cf}$, or 4-CmC, was significantly lower than that mediated by either ATP or histamine. Note that the effects mediated by $10 \mathrm{mM} \mathrm{Cf}$ on $\left[\mathrm{Ca}^{2+}\right]_{\mathrm{i}}$ were not further increased in RP- and $\mathrm{RD}$-cells using up to three times greater concentrations (data not shown).
These results provide a detailed description of the $\mathrm{Ca}^{2+}$ responses mediated by $\mathrm{IP}_{3} \mathrm{R}$ and RyR agonists in $\mathrm{RP}, \mathrm{RD}$, and $\mathrm{D}$ cells. This information will be used to interpret the effects mediated by arsenite in the three cell types. These results also provide evidence for the specificity of the effects mediated by Ry, which abolished the response mediated by Cf, with only a small effect on the ATP-dependent stimulation. Likewise, the specificity of the effects of 2-APB is demonstrated by the complete inhibition of the $\mathrm{Ca}^{2+}$ response evoked by ATP and by the lack of effect on the response mediated by $\mathrm{Cf}$.

Selection of Appropriate Treatment Conditions. After preliminary characterization of the $\mathrm{Ca}^{2+}$ responses mediated by $\mathrm{IP}_{3} \mathrm{R}$ and RyR agonists in the three cell types used in this study, we performed experiments to select conditions of arsenite exposure failing to produce detectable signs of cytotoxicity. As shown in Fig. 2, 6-hour exposure to $2.5 \mu \mathrm{M}$ arsenite failed to promote detectable toxic effects in RP, RD, or $D$ cells. Negative results were obtained using the trypan blue exclusion assay (Fig. 2A) or measuring the release of lactate dehydrogenase (data not shown). In addition, the three cell types maintained normal ATP levels (Fig. 2B) and $\mathrm{Ca}^{2+}$ -ATPase activities (Fig. 2C). Note that all the preceding negative results are associated with positive results obtained with other treatments (inset, Fig. 1, A-C).

To provide an additional relevant information documenting that under these conditions arsenite fails to affect the viability of the three cell types, we counted the number of viable cells after increasing the time intervals of post-treatment (6 hours) incubation in fresh culture medium. As indicated in Fig. 2, RP (Fig. 2D) or RD (Fig. 2E) cells treated with arsenite proliferated with kinetics superimposable on those of their untreated counterparts. D cells ceased to proliferate during differentiation and eventually lost this phenotype and proliferated once again after 24-48 hours of incubation in complete culture medium deprived of the differentiating agent. As indicated in Fig. 2F, however, there were no differences in the number of untreated or arsenite-treated D cells after increasing time intervals of incubation in fresh culture medium.

By all the preceding criteria, we can therefore safely conclude that a 6-hour exposure to $2.5 \mu \mathrm{M}$ arsenite fails to produce immediate or delayed signs of toxicity in the three cell types used in this study.

Effects of Arsenite on $\mathrm{Ca}^{2+}$ Homeostasis Are Not Mediated by ROS. The results illustrated in the previous section indicate that a 6 -hour exposure to $2.5 \mu \mathrm{M}$ arsenite fails to produce obvious signs of toxicity in the three cell types used in this study. This treatment, as we previously determined (Guidarelli et al., 2016b, 2017; Fiorani et al., 2018), is, however, associated with the formation of $\mathrm{mitoO}_{2}^{-}$, which can be clearly detected in RP cells in terms of inhibition of aconitase activity (Fig. 3A). Aconitase is an enzyme sensitive to $\mathrm{O}_{2}^{-}$-dependent inhibition (Yan et al., 1997; Gardner, 2002) and is largely localized in the mitochondria (Scandroglio et al., 2014). In addition, we recently determined that aconitase activity is only detectable in the mitochondrial fraction of U937 cells (Guidarelli et al., 2014). Figure $3 \mathrm{~A}$ also shows that $\mathrm{mitoO}_{2}^{-}$formation is suppressed by rotenone or AA. As a final note, arsenite failed to inhibit aconitase activity in RD cells, thereby indicating that the effects mediated by the respiratory 

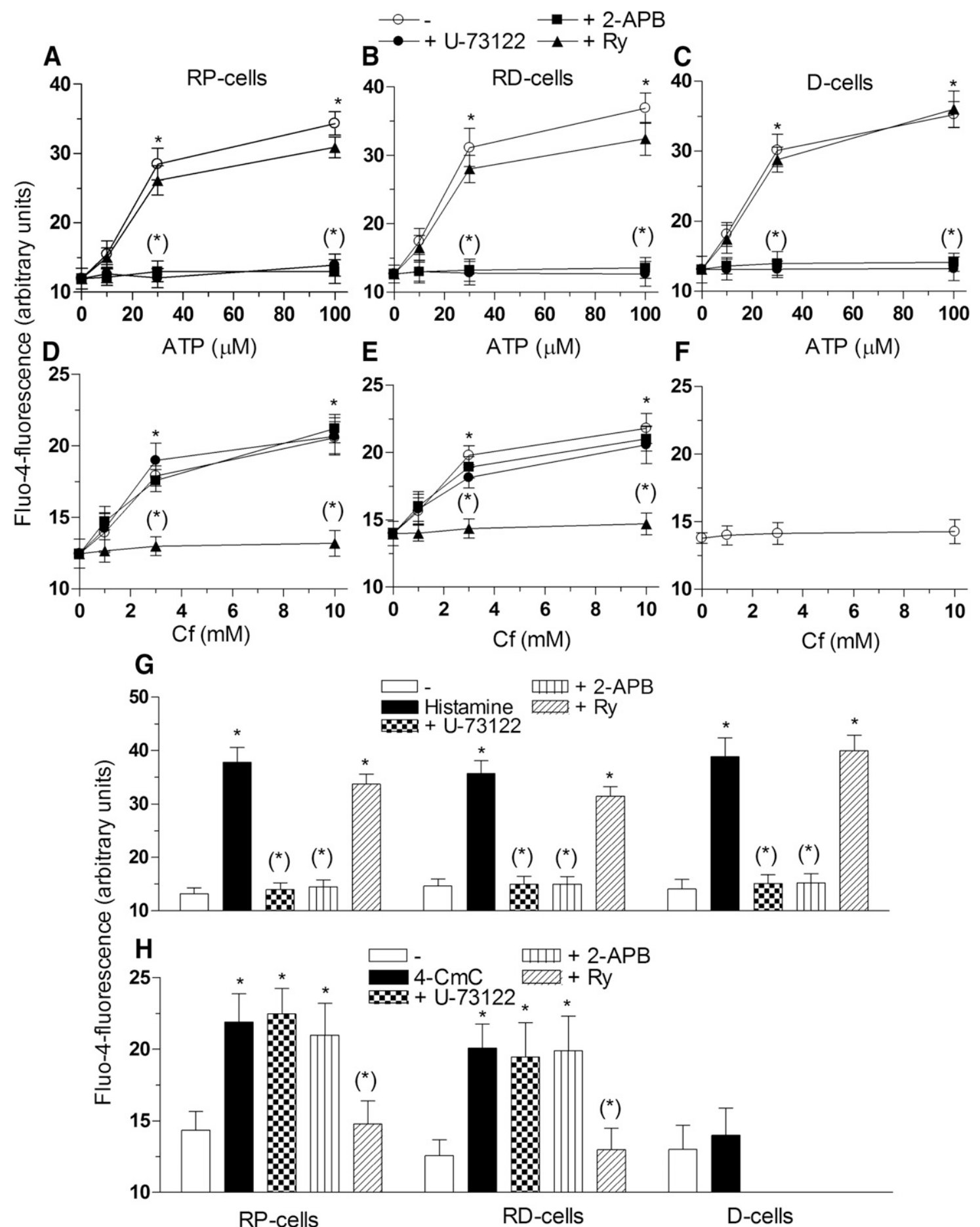

Fig. 1. Characterization of the $\mathrm{Ca}^{2+}$ responses mediated by $\mathrm{IP}_{3} \mathrm{R}$ and RyR agonists in $\mathrm{RP}, \mathrm{RD}$, and $\mathrm{D}$ cells. Fluo-4-acetoxymethyl ester-preloaded $\mathrm{RP}$ (A and $\mathrm{D}), \mathrm{RD}$ (B and $\mathrm{E})$, and D cells $(\mathrm{C}$ and $\mathrm{F})$ were exposed for 10 minutes to increasing concentrations of ATP $(\mathrm{A}-\mathrm{C})$ or $\mathrm{Cf}(\mathrm{D}-\mathrm{F})$. In some experiments, $2 \mu \mathrm{M}$ U-73122, $50 \mu \mathrm{M}$ 2-APB, or $20 \mu \mathrm{M}$ Ry was added to the cultures 5 minutes before ATP or Cf. Fluo-4-acetoxymethyl ester-preloaded RP, RD, and D cells were exposed for 10 minutes to $10 \mu \mathrm{M}$ histamine (G) or $300 \mu \mathrm{M}$ 4-CmC (H) in the absence or presence of U-73122, 2-APB, or Ry. Fluo-4-fluorescence was then quantified as detailed in Materials and Methods. Results represent the means \pm S.D. calculated from at least three separate experiments. ${ }^{*} P<0.01$ compared with untreated cells, ${ }^{*} P<0.01$, or cells treated with agonists (one-way ANOVA followed by Dunnett's test).

chain inhibitor rotenone in $\mathrm{RP}$ cells are mimicked by the respiration-deficient phenotype.

These results, although recapitulating our previous findings (Guidarelli et al., 2016a,b, 2017; Fiorani et al., 2018), provide a rationale and a strategy to address the specific question of whether $\mathrm{O}_{2}^{-}$and/or its dismutation product, $\mathrm{H}_{2} \mathrm{O}_{2}$, are causally involved in events associated with the effects of arsenite on $\mathrm{Ca}^{2+}$ homeostasis.

We therefore performed experiments in RP cells exposed for 6 hours to $2.5 \mu \mathrm{M}$ arsenite to test the effects of rotenone, or AA, in the ensuing increase in $\left[\mathrm{Ca}^{2+}\right]_{\mathrm{i}}$. As indicated in Fig. 3B, both agents failed to prevent the increase in $\left[\mathrm{Ca}^{2+}\right]_{\mathrm{i}}$ mediated by 


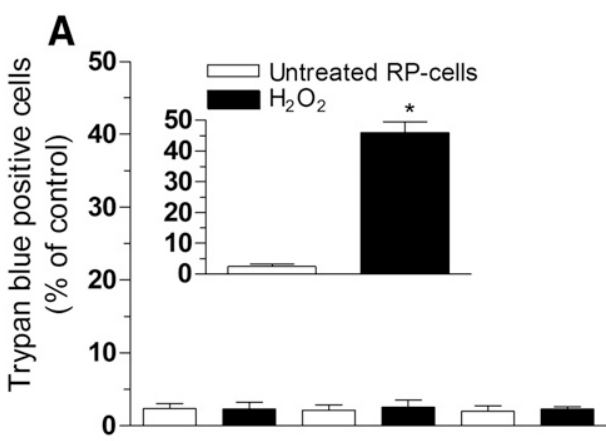

B
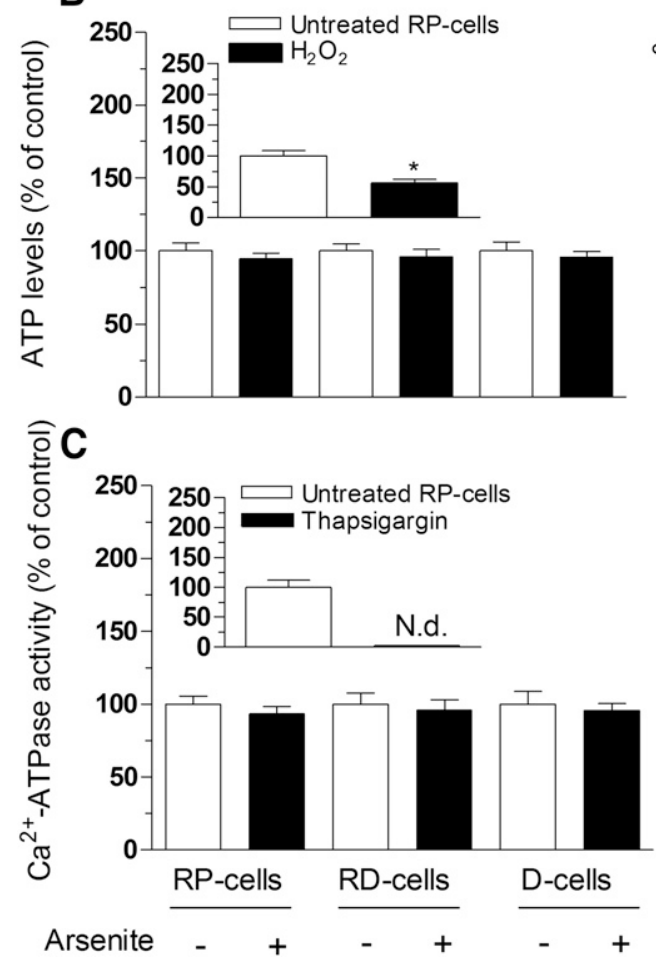

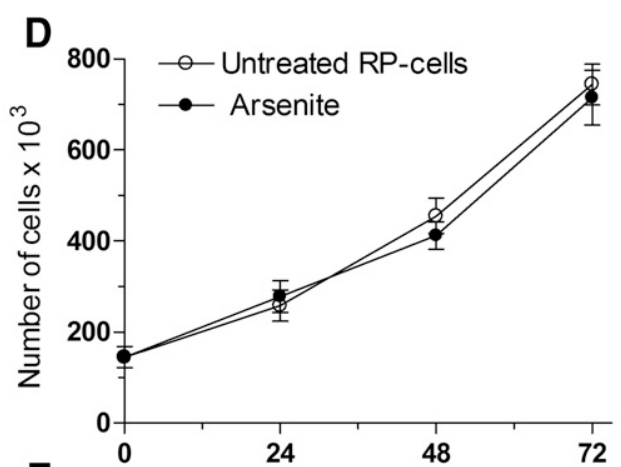

E

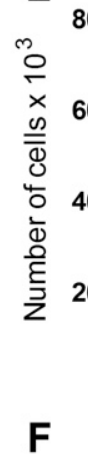

$\mathbf{F}$

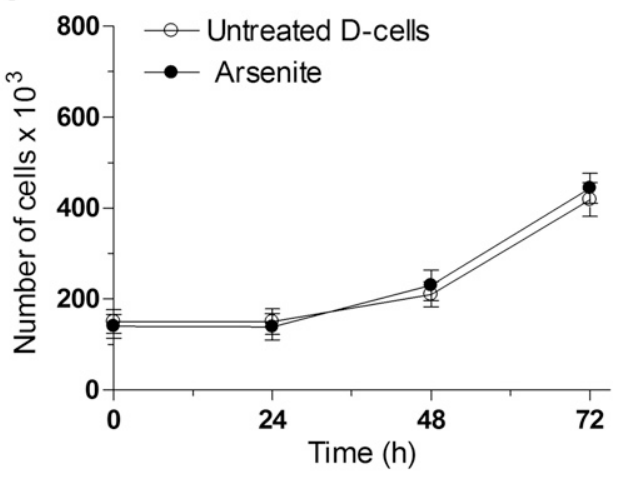

Fig. 2. The effects of arsenite on cell viability, energy status, and $\mathrm{Ca}^{2+}$-ATPase activity. RP, RD, and $\mathrm{D}$ cells were exposed for 6 hours to $2.5 \mu \mathrm{M}$ arsenite and then analyzed by counting the number of trypan blue-positive cells (A) and measuring their ATP levels (B) and $\mathrm{Ca}^{2+}$-ATPase activities (C). The positive controls were obtained using RP cells exposed for 120 (A, inset) or 30 (B, inset) minutes to $150 \mu \mathrm{M} \mathrm{H}^{2} \mathrm{O}_{2}$. Cells were exposed for 10 minutes to $1 \mu \mathrm{M}$ thapsigargin $(\mathrm{C}$, inset; n.d., not detectable). In other experiments, $R P(D), R D(E)$, and $D$ cells (F) were treated with arsenite as indicated in (A), washed, resuspended in fresh culture medium, and grown for up to 72 hours. The cell number was determined using a hemocytometer 24-72 hours after 6-hour exposure to the metalloid. Results are expressed as percentages of the untreated control and represent the means \pm S.D. calculated from at least three separate experiments. ${ }^{*} P<0.01$ compared with untreated cells (one-way ANOVA followed by Dunnett's test). the metalloid. Along the same lines, identical time-dependent increases in $\left[\mathrm{Ca}^{2+}\right]_{\mathrm{i}}$ were observed in $\mathrm{RP}$ and $\mathrm{RD}$ cells exposed for increasing time intervals to arsenite (Fig. 3C).

These results rule out the possibility that mitoO $\mathrm{O}_{2}^{-} \cdot \mathrm{H}_{2} \mathrm{O}_{2}$ contributes to events associated with altered $\mathrm{Ca}^{2+}$ homeostasis.

Arsenite Promotes the Sequential Release of $\mathrm{Ca}^{2+}$ from the $\mathbf{I P}_{\mathbf{3}} \mathbf{R}$ and the RyR. We performed experiments to determine the source of the $\mathrm{Ca}^{2+}$ mobilized by arsenite in $\mathrm{RP}$ cells exposed to arsenite. As indicated in Fig. 4A, the timedependent increase in $\left[\mathrm{Ca}^{2+}\right]_{\mathrm{i}}$ observed in these cells was prevented by 2 -APB and significantly blunted, but not abolished, by Ry. To obtain further information allowing interpretation of these results, we performed similar experiments in D cells. These cells responded to arsenite with a significantly lower time-dependent increase in $\left[\mathrm{Ca}^{2+}\right]_{\mathrm{i}}$ (Fig. 4B) compared with $\mathrm{RP}$ cells. In addition, the $\mathrm{Ca}^{2+}$ response detected in $\mathrm{D}$ cells was suppressed by 2-APB and unaffected by Ry. Note that similar low $\left[\mathrm{Ca}^{2+}\right]_{\mathrm{i}}$ are detected in $\mathrm{D}$ cells exposed to arsenite and in RP cells exposed to arsenite in combination with Ry. We could not test the effect of U-73122 on the increase in $\left[\mathrm{Ca}^{2+}\right]_{\mathrm{i}}$ mediated by arsenite because of its intrinsic toxicity. Loss of viability was detected in each of the three cell types after 6 hours' incubation with U-73122 or even after a 10-minute exposure to the inhibitor before the subsequent 6 -hour incubation in fresh medium. The susceptibility of tumor cells to PLC inhibitors has been reported elsewhere (Cardenas et al., 2016).

These results therefore indicate that arsenite induces a time-dependent increase in $\left[\mathrm{Ca}^{2+}\right]_{\mathrm{i}}$ likely attributable to mobilization of the cation from both the $\mathrm{IP}_{3} \mathrm{R}$ and RyR. The outcome of inhibitor studies in RP cells, combined with that from experiments using D cells, which fail to express the RyR, suggest that the initial low $\mathrm{Ca}^{2+}$ response mediated by stimulation of the $\mathrm{IP}_{3} \mathrm{R}$ is functional to recruitment of the RyR to contribute to a significantly greater increase in $\left[\mathrm{Ca}^{2+}\right]_{\mathrm{i}}$.

Characterization of the Effect of Arsenite on the $\mathbf{I P}_{\mathbf{3}} \mathbf{R}$ and RyR. The results summarized in the previous section suggest that a 6-hour exposure to $2.5 \mu \mathrm{M}$ arsenite causes a weak $\mathrm{IP}_{3} \mathrm{R}$ response. The simplest explanation obviously would be based on the concentration dependence of the effects mediated by arsenite, although alternative explanations are based on the possibility that the metalloid inhibits critical steps of the machinery involved in $\mathrm{Ca}^{2+}$ release by the $\mathrm{IP}_{3} R$. 


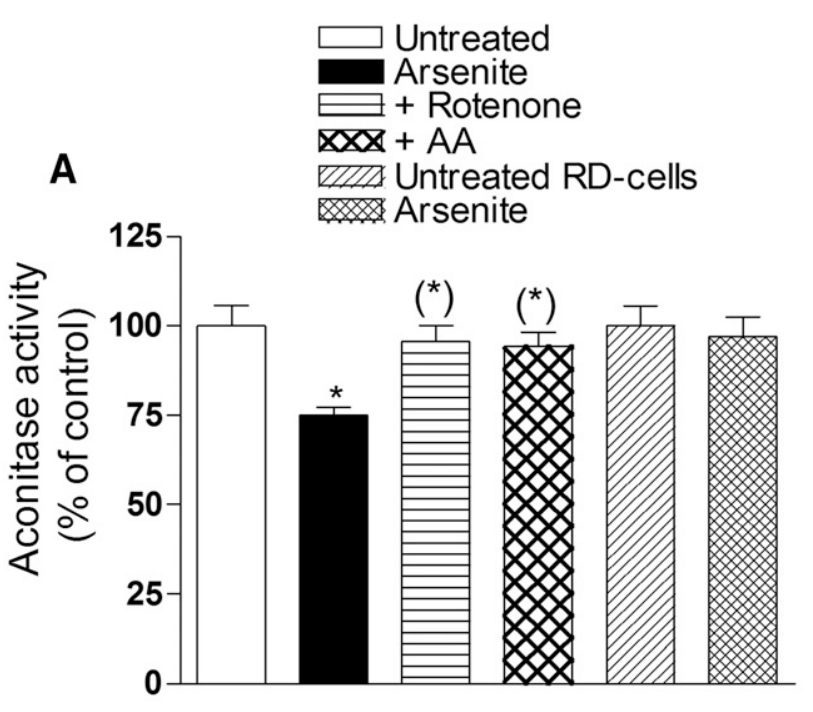

B
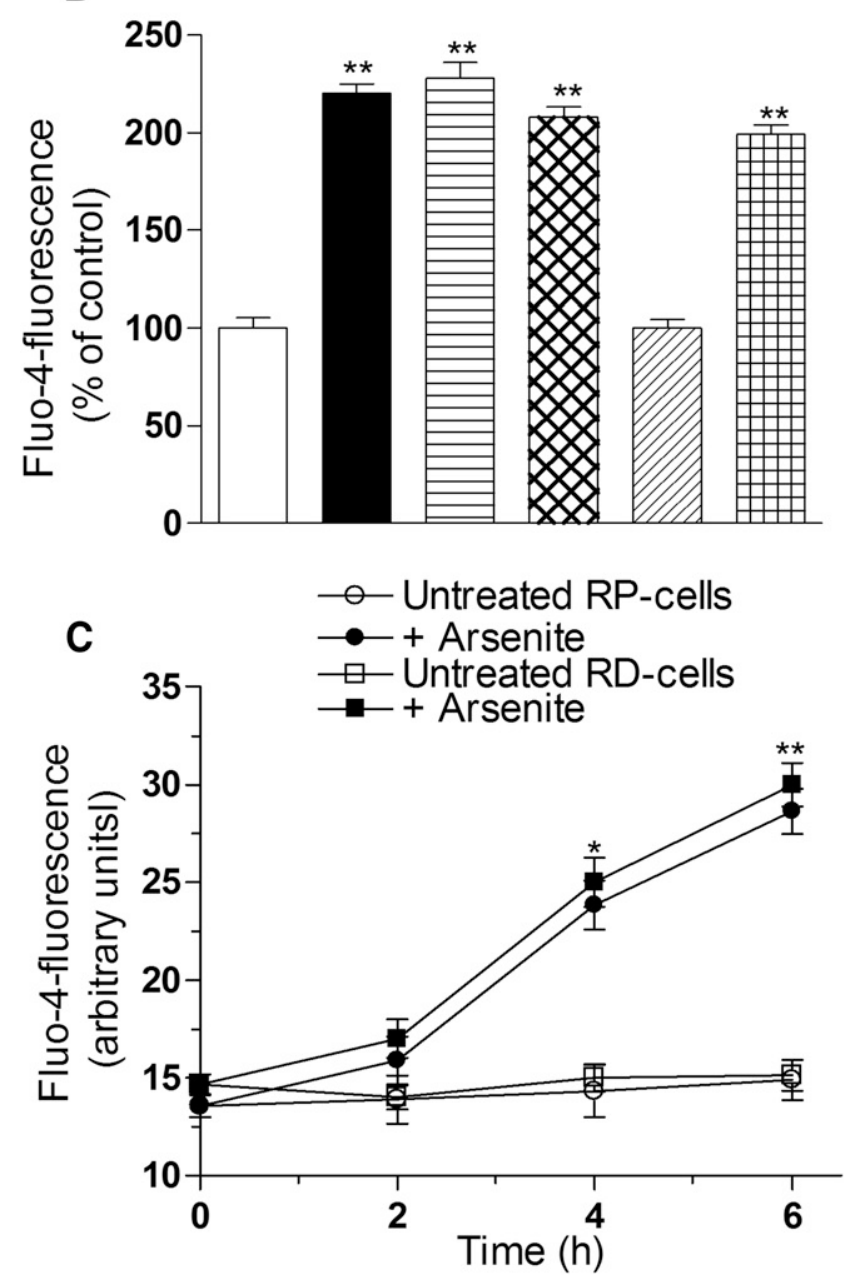

Fig. 3. The effects of arsenite on $\mathrm{Ca}^{2+}$ homeostasis are not mediated by ROS. Cells were exposed for 6 hours to $2.5 \mu \mathrm{M}$ arsenite in the absence or presence of either $0.5 \mu \mathrm{M}$ rotenone or $10 \mu \mathrm{M}$ AA and then analyzed for aconitase activity (A) or Fluo-4-fluorescence (B). Selected experiments were performed using RD cells either untreated or supplemented with arsenite. In other experiments, Fluo-4-acetoxymethyl ester-preloaded RP and RD cells were incubated for increasing time intervals with $2.5 \mu \mathrm{M}$ arsenite and then processed as indicated (C). Results represent the means \pm S.D. calculated from at least three separate experiments. $* P<0.05$; $* * P<0.01$ compared with untreated cells. $* P<0.05$ compared with cells treated with arsenite (two-way ANOVA followed by Bonferroni's test).
We therefore performed experiments to address these questions and initially determined the $\left[\mathrm{Ca}^{2+}\right]_{\mathrm{i}}$ resulting from a 6-hour exposure of $\mathrm{RP}$ cells to $2.5-10 \mu \mathrm{M}$ arsenite. The results illustrated in Fig. $4 \mathrm{C}$ indicate that, under these conditions, the metalloid promotes a remarkable and progressive increase in $\left[\mathrm{Ca}^{2+}\right]_{\mathrm{i}}$. Ry significantly blunted this $\mathrm{Ca}^{2+}$ response and abolished the concentration dependence of the effects of arsenite. The outcome of experiments using D cells indicated that 5 or $10 \mu \mathrm{M}$ arsenite fails to promote greater effects than $2.5 \mu \mathrm{M}$ arsenite (Fig. 4D). The curve obtained in these conditions was virtually identical to that obtained using $\mathrm{RP}$ cells supplemented with Ry (note the different ordinate axis). Interestingly, 2-APB also abolished the $\mathrm{Ca}^{2+}$ response mediated by the high concentrations of arsenite, thereby indicating that the metalloid, even under harsh conditions, fails to directly mobilize the cation from the RyR.

We then asked whether treatment with arsenite is associated with specific effects on the $\mathrm{IP}_{3} \mathrm{R}$ structure and function, thereby limiting the $\mathrm{Ca}^{2+}$ response mediated by its stimulation. For this purpose, we tested the effect of the $\mathrm{IP}_{3} \mathrm{R}$ agonist ATP under nonpermissive conditions for further $\mathrm{Ca}^{2+}$ release by the RyR. In these experiments, RP cells were treated for 6 hours with $2.5 \mu \mathrm{M}$ arsenite in the presence of Ry (Fig. 5A) and D cells with the metalloid alone (Fig. 5B) before 10-minute exposure to increasing concentrations of ATP/Ry (RP cells) or ATP alone (D cells). We found that the Fluo-4-dependent fluorescence responses mediated by ATP in arsenitesupplemented RP and D cells, although originating by the ordinate axis with an initial value corresponding to the fraction of the cation mobilized by the metalloid, rapidly converged with the dose-response curve obtained in naïve $\mathrm{RP}$ and D cells. As expected, under all the conditions, the $\mathrm{Ca}^{2+}$ responses were suppressed by 2 -APB (inset, Fig. 5).

Collectively, the results obtained in these experiments indicate that arsenite is a poor activator of the signaling leading to $\mathrm{Ca}^{2+}$ mobilization from the $\mathrm{IP}_{3} \mathrm{R}$ and that this response is maximally stimulated at $2.5 \mu \mathrm{M}$. Furthermore, arsenite does not limit the responsiveness of the $\mathrm{IP}_{3} \mathrm{R}$ to agonist stimulation. An additional conclusion derived from these experiments is that arsenite, even at very high concentrations, does not directly mobilize $\mathrm{Ca}^{2+}$ from the RyR.

Arsenite Fails to Affect the CICR Event Induced by Local Increases in $\left[\mathrm{Ca}^{2+}\right]_{i}$ in Close Proximity of the RyR or by More General Increases of the Cytosolic $\left[\mathbf{C a}^{2+}\right]_{\mathbf{i}}$ Induced by a $\mathbf{C a}^{2+}$ Ionophore. The results thus far presented provide evidence for specific and concentrationdependent effects of arsenite resulting in enhanced $\mathrm{Ca}^{2+}$ release from the RyR, under conditions in which the $\left[\mathrm{Ca}^{2+}\right]_{i}$ derived from the $\mathrm{IP}_{3} \mathrm{R}$ is weakly stimulated. Hence, a possible explanation would be that arsenite binds to specific thiols of the RyR, thereby causing its concentration-dependent sensitization to the increased $\left[\mathrm{Ca}^{2+}\right]_{\mathrm{i}}$. We therefore used 2 -APB to prevent $\mathrm{Ca}^{2+}$ release from the $\mathrm{IP}_{3} \mathrm{R}$, and the ensuing events and investigated the effect of arsenite on agonist-induced stimulation of $\mathrm{Ca}^{2+}$ release by the RyR. With this experiment, we were testing whether a local increase in $\left[\mathrm{Ca}^{2+}\right]_{\mathrm{i}}$ was able to trigger a greater release of the cation from the RyR in arsenitesupplemented cells.

$\mathrm{RP}$ cells were therefore exposed for 6 hours to $2.5 \mu \mathrm{M}$ arsenite in the presence of 2-APB, before 10 minutes' exposure to increasing concentrations of Cf (Fig. 6A). Interestingly, the Fluo-4-dependent fluorescence response observed under 

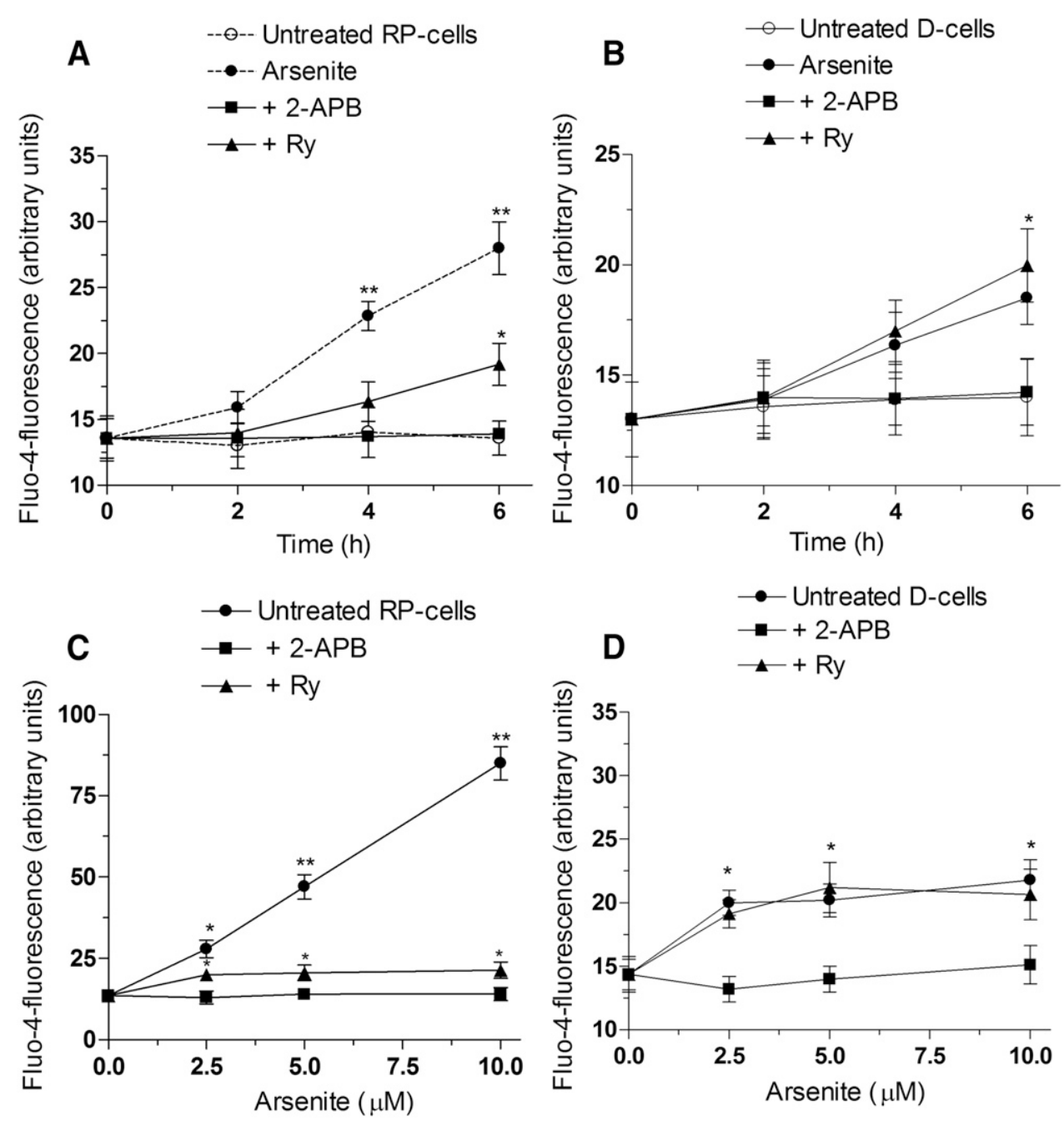

Fig. 4. Arsenite promotes a sustained increase in the $\left[\mathrm{Ca}^{2+}\right]_{\mathrm{i}}$ through a mechanism mediated by an initial small effect on the $\mathrm{IP}_{3} \mathrm{R}$ and a subsequent remarkable effect on the RyR. Fluo-4-acetoxymethyl ester-preloaded RP (A) and D cells (B) were incubated for increasing time intervals with $2.5 \mu \mathrm{M}$ arsenite in the absence or presence of 2-APB or Ry. Fluo-4acetoxymethyl ester-preloaded RP (C) and D cells (D) were incubated for 6 hours with increasing concentrations of arsenite in the absence or presence of 2-APB or Ry. After treatments, the cells were analyzed for Fluo-4-fluorescence. Results represent the means \pm S.D. calculated from at least three separate experiments. $* P<0.05$; $* * P<0.01$ compared with untreated cells (two-way ANOVA followed by Bonferroni's test). these conditions appeared identical to that mediated by $\mathrm{Cf}$ in cells pretreated with 2 -APB alone. Ry abolished the increase in $\left[\mathrm{Ca}^{2+}\right]_{\mathrm{i}}$ detected under both conditions (inset, Fig. 6A). These results indicate that arsenite fails to enhance the $\mathrm{Ca}^{2+}$ response mediated by a RyR agonist, which obviously increases the $\left[\mathrm{Ca}^{2+}\right]_{\mathrm{i}}$ in the same microdomains in which the RyR is located.

We therefore asked the question of whether the same is true under conditions in which the $\left[\mathrm{Ca}^{2+}\right]_{\mathrm{i}}$ is elevated with the use of A23187, $\mathrm{a} \mathrm{Ca}^{2+}$ ionophore (Peiretti et al., 1996). In these experiments, RP cells were treated with arsenite/2-APB, as indicated, subsequently stimulated with increasing concentrations of A23187 and finally analyzed to determine the Fluo4-fluorescence response. The increase in $\left[\mathrm{Ca}^{2+}\right]_{\mathrm{i}}$ detected under these conditions was virtually identical to that detected in cells pre-exposed to 2-APB alone and treated with the ionophore (Fig. 6B). Ry induced a significant and similar inhibition of both $\mathrm{Ca}^{2+}$ responses (inset, Fig. 6B). Hence, a general increase in $\left[\mathrm{Ca}^{2+}\right]_{\mathrm{i}}$ resulting from ionophore stimulation fails to trigger an enhanced CICR event in cells exposed to arsenite.

These results indicate that arsenite does not sensitize the RyR to the CICR event mediated by an increased $\left[\mathrm{Ca}^{2+}\right]_{\mathrm{i}}$ resulting from exposure to either a $\mathrm{RyR}$ agonist or a $\mathrm{Ca}^{2+}$ ionophore. In this perspective, the possibility of a general sensitizing effect to the $\left[\mathrm{Ca}^{2+}\right]_{i}$, even when the cation is released by the $\mathrm{IP}_{3} \mathrm{R}$, appears unlikely. These results are therefore indicative of specific intraluminal effects of arsenite on the crosstalk between the $\mathrm{IP}_{3} \mathrm{R}$ and $\mathrm{RyR}$, finally leading to a remarkable release of the cation in the cytosol.

\section{Discussion}

We have investigated the effect of a nontoxic concentration of arsenite on $\mathrm{Ca}^{2+}$ homeostasis with the aim of understanding the specific mechanism involved in this response, in the absence of confounding factors associated with the parallel triggering of toxic events. Using a well defined, versatile cellular system, we have demonstrated that the metalloid targets the $\mathrm{IP}_{3} \mathrm{R}$ to release low levels of $\mathrm{Ca}^{2+}$, an event associated with an ensuing much larger response mediated by the RyR. We also determined the specific effects of the metalloid on each of the two $\mathrm{Ca}^{2+}$ pools to conclude finally that the increased $\left[\mathrm{Ca}^{2+}\right]_{i}$ takes place as a consequence of ROSindependent, direct effects of arsenite on the intraluminal crosstalk between the two $\mathrm{Ca}^{2+}$ channels.

Our studies on the effects of arsenite on $\mathrm{Ca}^{2+}$ homeostasis were preceded by an initial characterization of the $\mathrm{Ca}^{2+}$ responses evoked by selected $\mathrm{IP}_{3} \mathrm{R}$ and $\mathrm{RyR}$ agonists in the three cell types used in this study. These experiments provided 

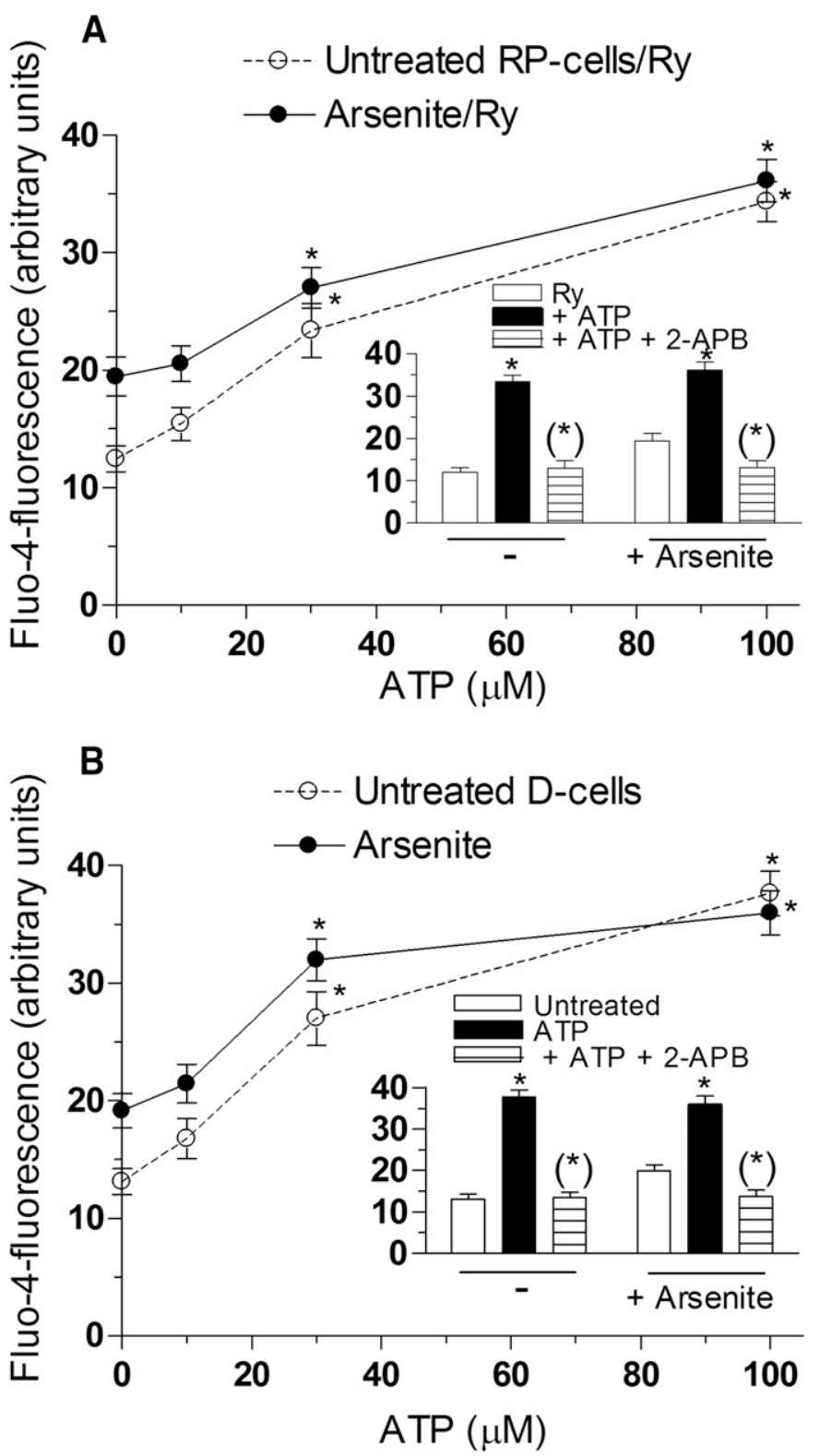

Fig. 5. Arsenite fails to affect the $\mathrm{Ca}^{2+}$ response mediated by the $\mathrm{IP}_{3} \mathrm{R}$ agonist ATP. Fluo-4-acetoxymethyl ester-preloaded RP (A) and D cells (B) were incubated for 6 hours with $2.5 \mu \mathrm{M}$ arsenite in the presence (A) or absence of Ry (B), washed, resuspended in fresh culture medium, and finally exposed for 10 minutes to increasing concentrations of ATP/Ry (A) or ATP alone (B). Also shown in the insets (A and B) are the effects of 2 -APB on the observed Fluo-4-fluorescence. Results represent the means \pm S.D. calculated from at least three separate experiments. $* P<0.01$ compared treated cells with Ry or arsenite/Ry treated cells. $* P<0.01$ compared with cells treated with Ry/ATP or arsenite/Ry/2-APB (one-way ANOVA followed by Dunnett's test).

results consistent with the well established notion that ATP, or histamine, causes a significant elevation in $\left[\mathrm{Ca}^{2+}\right]_{\mathrm{i}}$ by signaling through PLC and the $\mathrm{IP}_{3} \mathrm{R}$. The contribution of the $\mathrm{Ca}^{2+}$ released by the RyR in response to the increase in $\left[\mathrm{Ca}^{2+}\right]_{\mathrm{i}}$ instead appeared quite limited. We also noted that the effects mediated by ATP, or histamine, are identical in RP, RD, and D cells, thereby implying that the $\mathrm{IP}_{3} \mathrm{R}$ signaling is independent on the respiratory and differentiation status of the parental cell line. Additional information derived from this preliminary investigation is that stimulation of the RyR with $\mathrm{Cf}$ (or
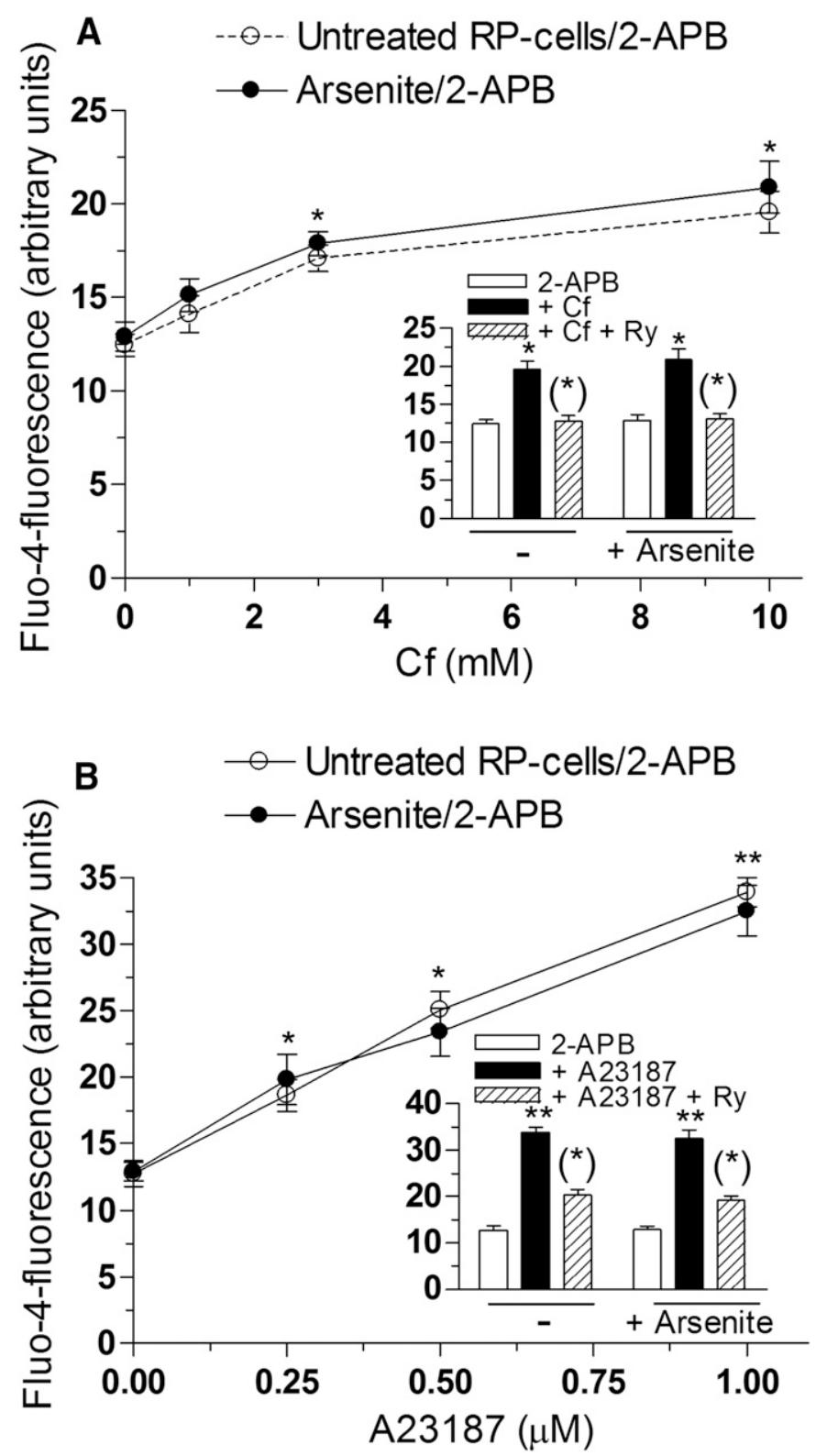

Fig. 6. Arsenite fails to affect the CICR event induced by local increases in $\mathrm{Ca}^{2+}$ concentration in the close proximity of the RyR (i.e., induced by Cf) or by more general increases of $\left[\mathrm{Ca}^{2+}\right]_{\mathrm{i}}$ (i.e., induced by a $\mathrm{Ca}^{2+}$ ionophore). Fluo-4acetoxymethyl ester-preloaded RP cells were incubated for 6 hours with $2.5 \mu \mathrm{M}$ arsenite and 2-APB, washed, resuspended in fresh culture medium, and subsequently exposed for 10 minutes to increasing concentrations of $\mathrm{Cf}(\mathrm{A})$ or A23187 (B). Also shown in the insets (A and B) are the effect of Ry on Fluo-4fluorescence responses detected in the two conditions. Results represent the means \pm S.D. calculated from at least three separate experiments. $* P<0.05$; **P $P 0.01$ compared treated cells with 2 -APB or arsenite/2-APB. $* P<0.05$ compared with cells treated with 2 -APB/Cf or arsenite/2-APB/Cf(A). ${ }^{*} P<0.05$ compared with cells treated with 2-APB/A23187 or arsenite/2-APB/A23187 (B) (one-way ANOVA followed by Dunnett's test).

4-CmC) provides a lower $\mathrm{Ca}^{2+}$ response with respect to that mediated by the $\mathrm{IP}_{3} \mathrm{R}$ agonists, restricted to the proliferating cells and insensitive to their respiratory status. Differentiation of RP cells to monocytes, as we reported several years ago (Guidarelli et al., 2009), instead leads to RyR downregulation and loss of responsiveness to RyR agonists.

Our studies on the effects of arsenite on $\mathrm{Ca}^{2+}$ homeostasis were also preceded by the demonstration that the experimental 
conditions used were not associated with detectable signs of toxicity or even with effects on the activity of the $\mathrm{Ca}^{2+}$-ATPases or the energy status of $\mathrm{RP}, \mathrm{RD}$, or $\mathrm{D}$ cells. This preliminary characterization is essential for correct interpretation of the significance of the results of our experiments investigating the impact of arsenite on $\mathrm{Ca}^{2+}$ homeostasis with use of U937 cells treated, or manipulated, to provide detailed information in this direction.

With this background information, we investigated the effects of arsenite on $\mathrm{Ca}^{2+}$ homeostasis in both RP and RD cells. As indicated in the Introduction, exposure to $2.5 \mu \mathrm{M}$ arsenite selectively promotes the formation of $\mathrm{mitoO}_{2}^{-}$in RP-cells (Guidarelli et al., 2016a,b, 2017; Fiorani et al., 2018). This notion was further established in this study by monitoring the inhibition of the activity of a mitoO $\mathrm{O}_{2}^{-}$-sensitive enzyme, aconitase, taking place via a mechanism suppressed by mitochondrial AA (Fiorani et al., 2015; Cantoni et al., 2017) rotenone or by the respiration-deficient phenotype; that is, RD cells failed to produce ROS in response to arsenite. It was then interesting to observe that all these treatments, or manipulations, suppressing mito $\mathrm{O}_{2}^{-}$formation failed to produce parallel effects on $\mathrm{Ca}^{2+}$ homeostasis. It follows that the metalloid directly promotes effects associated with an increased $\left[\mathrm{Ca}^{2+}\right]_{i}$, in the absence of an intermediate role mediated by mitoO $_{2}^{-}$ and/or its dismutation product $\mathrm{H}_{2} \mathrm{O}_{2}$. These effects are therefore most likely dependent on the direct binding of arsenite to specific protein-SH located in critical proteins regulating $\mathrm{Ca}^{2+}$ release from the ER.

This conclusion is particularly interesting since ROS mediate most of the toxic effects of arsenite, and their formation is most likely associated to $\mathrm{Ca}^{2+}$-dependent mechanisms (Flora, 2011). Under the specific conditions used in this study, the increased $\left[\mathrm{Ca}^{2+}\right]_{\mathrm{i}}$ may therefore result in enhanced mitochondrial $\mathrm{Ca}^{2+}$ accumulation, thereby fostering the formation of mito $\mathrm{O}_{2}^{-}$. This notion is currently being tested, but the preceding findings nevertheless lead us to propose that the direct effects of arsenite in the ER might represent an early and critical effect of the metalloid, likely responsible for the triggering of downstream genotoxicity and cytotoxicity.

Subsequent studies using various inhibitors and RP as well as $\mathrm{D}$ cells provided interesting information about the mechanism leading to the increase in $\left[\mathrm{Ca}^{2+}\right]_{\mathrm{i}}$-mediated by arsenite. Although it appears difficult to compare an acute agonistinduced $\mathrm{Ca}^{2+}$ response measured over a 10-minute time frame with the time-dependent sustained response mediated by arsenite over a 6 -hour period, we nevertheless noted remarkable differences in these conditions.

Indeed, we previously discussed that RyR agonists release much less $\mathrm{Ca}^{2+}$ than $\mathrm{IP}_{3} \mathrm{R}$ agonists and that the CICR response provides a minor contribution to the large $\mathrm{Ca}^{2+}$ response mediated by the $\mathrm{IP}_{3} \mathrm{R}$ agonists. The scenario was completely different after exposure to arsenite. The overall information provided by the results presented in this study demonstrates the existence of a dichotomy between the persistently low $\mathrm{Ca}^{2+}$ response derived from $\mathrm{IP}_{3} \mathrm{R}$ and the remarkable and progressive increase in the amount of $\mathrm{Ca}^{2+}$ subsequently released by the RyR.

The first observation was integrated by the information deriving from two separate approaches. The first was the demonstration that the $\mathrm{IP}_{3} \mathrm{R}$-mediated response (i.e., the Ry-insensitive elevation of $\mathrm{Ca}^{2+}$ detected in $\mathrm{RP}$ cells or the overall response detected in $\mathrm{D}$ cells is not further increased by arsenite concentrations up to $10 \mu \mathrm{M}$. The second approach instead produced results arguing against the possibility that the saturable mechanism is dependent on putative inhibitory effects of arsenite on $\mathrm{Ca}^{2+}$ release by the $\mathrm{IP}_{3} \mathrm{R}$. Using the same conditions described in the preceding section to prevent the release of $\mathrm{Ca}^{2+}$ from the $\mathrm{RyR}$, we indeed demonstrated that arsenite does not affect the $\mathrm{Ca}^{2+}$ response mediated by the $\mathrm{IP}_{3} \mathrm{R}$ agonist ATP.

Collectively, the results obtained in these experiments indicate that arsenite is a poor activator of the signaling leading to $\mathrm{Ca}^{2+}$ mobilization from the $\mathrm{IP}_{3} \mathrm{R}$ and that this response is maximally stimulated at $2.5 \mu \mathrm{M}$. The effects of arsenite were instead concentration-dependent under conditions permissive for the involvement of the RyR in the overall $\mathrm{Ca}^{2+}$ response. This remarkable response was not due to direct stimulation of $\mathrm{Ca}^{2+}$ release by the RyR since high concentrations of arsenite failed to increase the $\left[\mathrm{Ca}^{2+}\right]_{\mathrm{i}}$ under conditions preventing the mobilization of the cation from the $\mathrm{IP}_{3} \mathrm{R}$.

Collectively, the results thus far discussed indicate that the $\mathrm{Ca}^{2+}$ released by the $\mathrm{IP}_{3} \mathrm{R}$, remaining low and constant at increasing arsenite concentrations, leads to further release of the cation from the RyR, which instead becomes progressively more elevated at increasing concentrations of the metalloid. Hence, these results imply that arsenite sensitizes the RyR to events other than then the increase in $\left[\mathrm{Ca}^{2+}\right]_{\mathrm{i}}$, likely dependent on direct effects on the intraluminal crosstalk between the $\mathrm{IP}_{3} \mathrm{R}$ and RyR.

This notion is also consistent with other findings obtained in experiments using RyR agonist- or A23187 ionophore-induced stimulation. Our results, indeed, argued against a general sensitizing effect of arsenite on the RyR. It rather appeared that the sensitization, clearly appreciable after the $\mathrm{IP}_{3} \mathrm{R}$ stimulation mediated by the metalloid, was not apparent under conditions in which the cation was released by agonistmediated stimulation of the RyR itself or eventually derived from the external milieu.

We are therefore left with the only possibility that the remarkable release of RyR-derived $\mathrm{Ca}^{2+}$ detected in response to arsenite is largely mediated by mechanisms regulated within the ER.

In conclusion, using well defined cellular systems and conditions, we investigated the mechanism whereby nontoxic concentrations of arsenite, which nevertheless significantly and selectively stimulate mitoO $_{2}^{-}$formation, lead to an increased $\left[\mathrm{Ca}^{2+}\right]_{\mathrm{i}}$. The metalloid promoted a sustained increase in $\left[\mathrm{Ca}^{2+}\right]_{\mathrm{i}}$ through a mechanism independent on the effect of these radicals and associated with an initial mobilization of low levels of the cation from the $\mathrm{IP}_{3} \mathrm{R}$. This event, although limited and saturable, was critical for the triggering of further $\mathrm{Ca}^{2+}$ release from the RyR that was, however, concentration dependently modulated by further effects of arsenite on the intraluminal crosstalk between the $\mathrm{IP}_{3} \mathrm{R}$ and the RyR (Fig. 7). Our results indicate that this response accounts for the very large proportion of the overall $\mathrm{Ca}^{2+}$ response evoked by arsenite under the conditions used in the present investigation.

The present study therefore provides critical information for understanding the mechanism whereby arsenite promotes its deleterious effects in mammalian cells. We have identified important direct effects mediated by the metalloid in the ER, critically contributing to the increase in $\left[\mathrm{Ca}^{2+}\right]_{\mathrm{i}}$, the likely primum movens of the overall cellular response to arsenite. It 


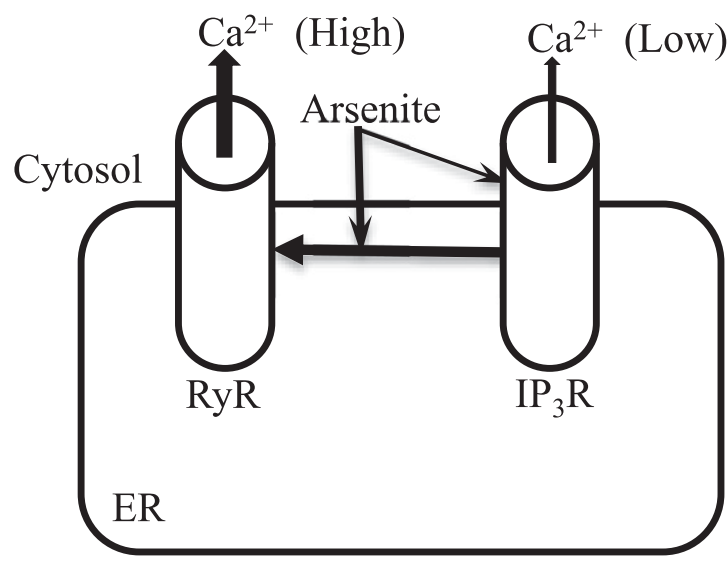

Fig. 7. Mechanism whereby a low concentration of arsenite mobilizes $\mathrm{Ca}^{2+}$ from the ER. Arsenite elevates the $\left[\mathrm{Ca}^{2+}\right]_{\mathrm{i}}$ by directly targeting the $\mathrm{IP}_{3} \mathrm{R}$ and its intraluminal crosstalk with the RyR.

is easy to predict that these events will also regulate accumulation of the cation in specific compartments, such as the mitochondria. Mitochondrial $\mathrm{Ca}^{2+}$ would then critically regulate processes leading to $\mathrm{mitoO}_{2}^{-}$formation, thereby promoting the ensuing downstream effects, as the strand scission of genomic DNA, even at low and nontoxic arsenite concentrations. Mitochondrial $\mathrm{Ca}^{2+}$, however, also mediates processes leading to cell death, such as mitochondrial dysfunction and permeability transition (Gorlach et al., 2015; Csordás et al., 2018). With this perspective, the mechanisms identified in this study should be considered relevant also for the induction of apoptosis caused by a more prolonged exposure to or exposure to greater concentrations of arsenite.

\section{Authorship Contributions}

Participated in research design: Guidarelli, Fiorani, Cantoni.

Conducted experiments: Guidarelli, Fiorani.

Performed data analysis: Guidarelli, Fiorani, Cantoni.

Wrote or contributed to the writing of the manuscript: Cantoni, Guidarelli, Fiorani.

\section{References}

Banerjee C, Goswami R, Datta S, Rajagopal R, and Mazumder S (2011) Arsenicinduced alteration in intracellular calcium homeostasis induces head kidney macrophage apoptosis involving the activation of calpain-2 and ERK in Clarias batrachus. Toxicol Appl Pharmacol 256:44-51.

Berridge MJ (2016) The inositol trisphosphate/calcium signaling pathway in health and disease. Physiol Rev 96:1261-1296.

Cantoni O, Guidarelli A, and Fiorani M (2017) Mitochondrial uptake and accumulation of vitamin C: what can we learn from cell culture studies? Antioxid Redox Signal DOI: 10.1089/ars.2017.7253 [published ahead of print].

Cárdenas C, Müller M, McNeal A, Lovy A, Jaña F, Bustos G, Urra F, Smith N, Molgó J, Diehl JA, et al. (2016) Selective vulnerability of cancer cells by inhibition of $\mathrm{Ca}(2+)$ transfer from endoplasmic reticulum to mitochondria [published correction appears in Cell Rep (2016) 15:219-220]. Cell Rep 14:2313-2324.

Chen A, Cao EH, Zhang TC, and Qin JF (2002) Arsenite-induced reactive oxygen species and the repression of alpha-tocopherol in the MGC-803 cells. Eur J Pharmacol 448:11-18.

Chernorudskiy AL and Zito E (2017) Regulation of calcium homeostasis by ER redox: a close-up of the ER/mitochondria connection. J Mol Biol 429:620-632.

Clapham DE (2007) Calcium signaling. Cell 131:1047-1058.

Clementi E, Guidarelli A, and Cantoni O (1998) The inositol 1,4,5-trisphosphategenerating agonist ATP enhances DNA cleavage induced by tert-butylhydroperoxide. Exp Cell Res 239:175-178.

Csordás G, Weaver D, and Hajnóczky G (2018) Endoplasmic reticulum-mitochondrial contactology: structure and signaling functions. Trends Cell Biol 28:523-540 DOI: 10.1016/j.tcb.2018.02.009.

Fiorani M, Azzolini C, Cerioni L, Scotti M, Guidarelli A, Ciacci C, and Cantoni O (2015) The mitochondrial transporter of ascorbic acid functions with high affinity in the presence of low millimolar concentrations of sodium and in the absence of calcium and magnesium. Biochim Biophys Acta 1848:1393-1401.

Fiorani M, Guidarelli A, Capellacci V, Cerioni L, Crinelli R, and Cantoni O (2018) The dual role of mitochondrial superoxide in arsenite toxicity: signaling at the boundary between apoptotic commitment and cytoprotection. Toxicol Appl Pharmacol 345:26-35.

Flora SJ (2011) Arsenic-induced oxidative stress and its reversibility. Free Radic Biol Med 51:257-281.

Gardner PR (2002) Aconitase: sensitive target and measure of superoxide. Methods Enzymol 349:9-23.

Görlach A, Bertram K, Hudecova S, and Krizanova O (2015) Calcium and ROS: a mutual interplay. Redox Biol 6:260-271.

Guidarelli A, Carloni S, Balduini W, Fiorani M, and Cantoni O (2016a) Mitochondrial ascorbic acid prevents mitochondrial $\mathrm{O}_{2}{ }^{-}$formation, an event critical for U937 cell apoptosis induced by arsenite through both autophagic-dependent and independent mechanisms. Biofactors 42:190-200.

Guidarelli A, Cerioni L, Fiorani M, Azzolini C, and Cantoni O (2014) Mitochondrial ascorbic acid is responsible for enhanced susceptibility of U937 cells to the toxic effects of peroxynitrite. Biofactors 40:236-246.

Guidarelli A, Cerioni L, Fiorani M, and Cantoni O (2009) Differentiation-associated loss of ryanodine receptors: a strategy adopted by monocytes/macrophages to prevent the DNA single-strand breakage induced by peroxynitrite. J Immunol 183: $4449-4457$.

Guidarelli A, Fiorani M, Carloni S, Cerioni L, Balduini W, and Cantoni O (2016b) The study of the mechanism of arsenite toxicity in respiration-deficient cells reveals that NADPH oxidase-derived superoxide promotes the same downstream events mediated by mitochondrial superoxide in respiration-proficient cells. Toxicol Appl Pharmacol 307:35-44.

Guidarelli A, Fiorani M, Cerioni L, Scotti M, and Cantoni O (2017) Arsenite induces DNA damage via mitochondrial ROS and induction of mitochondrial permeability transition. Biofactors 43:673-684

Guidarelli A, Fiorani M, Tommasini I, Cerioni L, and Cantoni O (2006) Reduced mitochondrial formation of $\left.\mathrm{H}_{2} \mathrm{O}_{2} \mathrm{O}_{2}\right)$ is responsible for resistance of dimethyl sulfoxide differentiated U937 cells to peroxynitrite. Int J Biochem Cell Biol 38:56-68.

Hill SJ, Ganellin CR, Timmerman H, Schwartz JC, Shankley NP, Young JM, Schunack W, Levi R, and Haas HL (1997) International Union of Pharmacology. XIII. Classification of histamine receptors. Pharmacol Rev 49:253-278.

Hoonjan M, Jadhav V, and Bhatt P (2018) Arsenic trioxide: insights into its evolution to an anticancer agent. J Biol Inorg Chem 23:313-329 DOI:10.1007/s00775-018-1537-9.

Hosoi E, Nishizaki C, Gallagher KL, Wyre HW, Matsuo Y, and Sei Y (2001) Expression of the ryanodine receptor isoforms in immune cells. J Immunol 167: 4887-4894.

Hsu WL, Tsai MH, Lin MW, Chiu YC, Lu JH, Chang CH, Yu HS, and Yoshioka T (2012) Differential effects of arsenic on calcium signaling in primary keratinocytes and malignant (HSC-1) cells. Cell Calcium 52:161-169.

Lee MY, Lee YH, Lim KM, Chung SM, Bae ON, Kim H, Lee CR, Park JD, and Chung JH (2005) Inorganic arsenite potentiates vasoconstriction through calcium sensitization in vascular smooth muscle. Environ Health Perspect 113:1330-1335.

Meissner G (2017) The structural basis of ryanodine receptor ion channel function. $J$ Gen Physiol 149:1065-1089.

Minatel BC, Sage AP, Anderson C, Hubaux R, Marshall EA, Lam WL, and Martinez VD (2018) Environmental arsenic exposure: from genetic susceptibility to pathogenesis. Environ Int 112:183-197.

Pachauri V, Mehta A, Mishra D, and Flora SJ (2013) Arsenic induced neuronal apoptosis in Guinea pigs is $\mathrm{Ca}^{2+}$ dependent and abrogated by chelation therapy: role of voltage gated calcium channels. Neurotoxicology 35:137-145.

Peiretti F, Fossat C, Anfosso F, Alessi MC, Henry M, Juhan-Vague I, and Nalbone G (1996) Increase in cytosolic calcium upregulates the synthesis of type 1 plasminogen activator inhibitor in the human histiocytic cell line U937. Blood 87:162-173.

Raffaello A, Mammucari C, Gherardi G, and Rizzuto R (2016) Calcium at the center of cell signaling: interplay between endoplasmic reticulum, mitochondria, and lysosomes. Trends Biochem Sci 41:1035-1049.

Scandroglio F, Tórtora V, Radi R, and Castro L (2014) Metabolic control analysis of mitochondrial aconitase: influence over respiration and mitochondrial superoxide and hydrogen peroxide production. Free Radic Res 48:684-693.

Scotti M, Fiorani M, Guidarelli A, and Cantoni O (2018) Differentiation of promonocytic U937 Cells to monocytes is associated with reduced mitochondrial transport of ascorbic acid. Oxid Med Cell Longev 2018:4194502.

Stocchi V, Cucchiarini L, Magnani M, Chiarantini L, Palma P, and Crescentini G (1985) Simultaneous extraction and reverse-phase high-performance liquid chromatographic determination of adenine and pyridine nucleotides in human red blood cells. Anal Biochem 146:118-124.

Sugiyama T, Yamamoto-Hino M, Miyawaki A, Furuichi T, Mikoshiba K, and Hasegawa M (1994) Subtypes of inositol 1,4,5-trisphosphate receptor in human hematopoietic cell lines: dynamic aspects of their cell-type specific expression. FEBS Lett 349:191-196.

Suriyo T, Watcharasit P, Thiantanawat A, and Satayavivad J (2012) Arsenite promotes apoptosis and dysfunction in microvascular endothelial cells via an alteration of intracellular calcium homeostasis. Toxicol In Vitro 26:386-395.

Yan LJ, Levine RL, and Sohal RS (1997) Oxidative damage during aging targets mitochondrial aconitase. Proc Natl Acad Sci USA 94:11168-11172.

Address correspondence to: Orazio Cantoni, Dipartimento di Scienze Biomolecolari, Sezione di Farmacologia e Farmacognosia, Università degli Studi di Urbino, Urbino (PU), Italy. E-mail: orazio.cantoni@uniurb.it 